\title{
Long-chain alkyl ester of AMP acts as an antagonist of glucose-induced signal transduction that mediates activation of plasma membrane proton pump in Saccharomyces cerevisiae
}

\author{
Toshio Tanaka, Keiji Nakayama, Kiyotaka Machida \\ and Makoto Taniguchi
}

\begin{abstract}
Author for correspondence: Toshio Tanaka. Tel: +8166605 3163. Fax: +81666053164 e-mail: tanakato@sci.osaka-cu.ac.jp
\end{abstract}

Department of Bio- and Geoscience, Graduate School of Science, Osaka City University, 3-3-138 Sugimoto, Sumiyoshi-ku, Osaka 558-8585, Japan
One of the long-chain alkyl esters of AMP, adenosine 5'-hexadecylphosphate (AMPC16), exhibited a cytotoxic growth inhibitory effect on cells of various yeast strains. The growth inhibitory effect of AMPC16 on Saccharomyces cerevisiae cells was observed only in medium containing $\mathbf{M g}^{2+}$, which accelerated cellular uptake of the nucleotide analogue. In the presence of $\mathrm{Mg}^{2+}$, AMPC16 completely inhibited glucose-induced extracellular acidification by the intact cells and also interfered with activation of the plasma membrane ATPase, but did not directly inhibit the ATPase activity itself. AMPC16 treatment prevented cells from increasing their intracellular sn-1,2diacylglycerol (DAG) level in response to glucose, whereas the inhibition of proton extrusion by the cells could be largely reversed by the coaddition of a membrane-permeable DAG analogue. The DAG analogue, a physiological activator of protein kinase C (PKC), was not protective against the inhibition of glucose-induced proton extrusion by staurosporine, which is capable of directly interfering with the action of PKC. These results implied that AMPC16 caused a $\mathrm{Mg}^{2+}$-dependent cytotoxic effect on Sac. cerevisiae cells by interfering with a phosphatidylinositol type of signal that mediates activation of the plasma membrane proton pump.

Keywords: Saccharomyces cerevisiae, plasma membrane $\mathrm{H}^{+}$-ATPase, signal transduction, nucleotide analogue

\section{INTRODUCTION}

AMP can be structurally modified to contain long-chain alkylphosphate esters, which can inhibit adenylate cyclase (Hynie \& Smrt, 1978) and ribonuclease (Yasuda \& Inoue, 1983) to varying extents, depending on the length of the alkyl side chain. Among these analogues, adenosine 5'-hexadecylphosphate (AMPC16, see Fig. 1) has a structure quite analogous to that of adenosine $5^{\prime}$-acylphosphates such as adenosine 5'-palmitoyl-

Abbreviations: AMPC12, adenosine 5'-dodecylphosphate; AMPC16, adenosine 5'-hexadecylphosphate; AMPC20, adenosine 5'-eicosylphosphate; DAG, diacylglycerol; DES, diethylstilboestrol; PKC, protein kinase C; UMPC12, uridine 5'-dodecylphosphate; UMPC16, uridine 5'hexadecylphosphate; UMPC20, uridine 5'-eicosylphosphate. phosphate, the transient intermediate product of the palmitoyl-CoA synthetic reaction combining palmitic acid and ATP. As can be predicted from the structural analogy, AMPC16 inhibits the long-chain fatty acylCoA synthetase of rat liver microsomes in a noncompetitive fashion (Shiraishi et al., 1994). It remains unknown whether these AMP analogues can influence the cell proliferation of mammals or other organisms via the inhibition of enzyme activities.

In our screening study of chemical antagonists of signal transduction, long-chain alkyl esters containing UMP were synthesized, in addition to those containing AMP, and their activities were evaluated in terms of an inhibitory effect against the pheromone-triggered mating process of Saccharomyces cerevisiae (Machida et al., 1997). Uridine 5'-hexadecylphosphate (UMPC16, 
see Fig. 1) specifically inhibited sexual agglutination between cells of the a- and $\alpha$-mating types initiated via the binding of $\mathbf{a}$ and $\alpha$ pheromones with the corresponding receptor molecules which function to activate a GTP-binding protein on the cell surface of the opposite mating type (Manfredi et al., 1996). Similar inhibition was also observed with AMPC16 but it was accompanied by an inhibition against vegetative cell growth, which was in agreement with a previous finding on the role of the AMP analogue as an inhibitor of longchain acyl-CoA synthetase (Shiraishi et al., 1994). In addition, the growth inhibition by AMPC16 may reflect its interference with a cAMP-dependent cell cycle mechanism (Hynie \& Smrt, 1978; Morishita et al., 1995). In the present study, we examined the antimicrobial activities of these nucleotide analogues against a wide variety of bacteria, yeast and fungi, and characterized the mechanism of the $\mathrm{Mg}^{2+}$-dependent cytotoxic action of AMPC16 against Sac. cerevisiae cells.

\section{METHODS}

Microbial strains and media. Sac. cerevisiae IFO 0203 was mainly used in addition to some other yeast strains (see Table 1) and the bacterial strains such as Escherichia coli IFO 3545, Staphylococcus aureus NCTC 8530 and Bacillus subtilis IFO 3007. The following strains of filamentous fungi were also used: Aspergillus niger ATCC 6275, Penicillium chrysogenum IFO 4626 and Mucor mucedo IFO 7684. The growth properties of Sac. cerevisiae IFO 0203 cells were examined in YPD medium which contained $1 \%$ yeast extract, $2 \%$ peptone and $2 \%$ glucose at $30^{\circ} \mathrm{C}$. YPG medium consisted of $1 \%$ yeast extract, $2 \%$ peptone and $3 \%$ glycerol.

Measurement of yeast cell growth. Antimicrobial activities of nucleotide analogues were assayed by the serial broth dilution method which has been conventionally used in our studies on naturally occurring antibiotics (Akeda et al., 1995; Ueki et al., 1996). In this method, the MIC represents the minimum concentration of nucleotide analogue which can absolutely prevent the turbidity increase due to cell growth (Baltch et al., 1998; Kohner et al., 1997). Cells of Sac. cerevisiae IFO 0203 were grown overnight in YPD medium with vigorous shaking and were inoculated into freshly prepared medium to give an initial cell density of approximately $10^{6}$ cells $\mathrm{ml}^{-1}$. Cells were

Table 1. MICs of AMPC16 on yeast cell growth

\begin{tabular}{|c|c|c|}
\hline \multirow[t]{2}{*}{ Test organism } & \multicolumn{2}{|c|}{$\begin{array}{c}\text { MIC } \\
\left(\mu \mathrm{g} \mathrm{ml}^{-1}\right) \text { with }\end{array}$} \\
\hline & None & $\mathrm{Mg}^{2+*}$ \\
\hline Saccharomyces cerevisiae IFO 0203 & $>100$ & $6 \cdot 25$ \\
\hline Schizosaccharomyces pombe IFO 0342 & $6 \cdot 25$ & $3 \cdot 13$ \\
\hline Candida albicans IFO 1061 & $>100$ & $25 \cdot 0$ \\
\hline Candida saitoana IFO 0768 & $>100$ & $12 \cdot 5$ \\
\hline Rhodotorula rubra IFO 0001 & $>100$ & $>100$ \\
\hline Hansenula anomala IFO 0136 & $>100$ & $12 \cdot 5$ \\
\hline
\end{tabular}

* Assayed in the presence of $10 \mathrm{mM} \mathrm{MgSO}_{4}$. then grown with or without AMPC16 with vigorous shaking and portions were withdrawn at various times to measure the cell density at $\mathrm{OD}_{610}$ and to measure the c.f.u. as a measure of the viable cell number (Machida et al., 1999). Cell viability was also determined by the methylene blue staining method (Rodriguez \& Parks, 1981) with a microscopic examination, in which the initial cell density was adjusted to $10^{7} \mathrm{ml}^{-1}$.

Synthesis of uridine and adenosine $\mathbf{5}^{\prime}$-alkylphosphates. The following nucleotide analogues were synthesized as described previously (Machida et al., 1997): uridine 5'-dodecylphopshate (UMPC12), UMPC16, adenosine 5'-dodecylphosphate (AMPC12) and AMPC16. In the present study, uridine 5'-eicosylphosphate (UMPC20) was synthesized by exactly following the procedure for UMPC16 synthesis except that eicosyl alcohol was used as the alkyl donor in the reaction. Shiraishi et al. (1994) have reported the synthesis of adenosine $5^{\prime}$-eicosylphosphate (AMPC20) by a condensation reaction between AMP and eicosyl alcohol, but we synthesized it by following our previously described method using AMP and the corresponding alkylbromide. ${ }^{1} \mathrm{H}$ - and ${ }^{13} \mathrm{C}-\mathrm{NMR}$ spectral data of UMPC20 and AMPC20 were obtained using a JEOL JNM-400GX spectrometer in DMSO- $d_{6}$ and showed good correlation to those obtained with UMPC16 (Machida et al., 1997) and AMPC20 (Shiraishi et al., 1994), respectively. The absolute chemical structures of UMPC20 and AMPC20 were ultimately confirmed by their mass spectra, with $m / z 603$ for $\mathrm{C}_{29} \mathrm{H}_{52} \mathrm{~N}_{2} \mathrm{O}_{9} \mathrm{P}\left(\mathrm{M}^{+}-1\right)$ and $m / z 626$ for $\mathrm{C}_{30} \mathrm{H}_{53} \mathrm{~N}_{5} \mathrm{O}_{7} \mathrm{P}\left(\mathrm{M}^{+}-\right.$ $1)$, respectively. Fig. 1 shows the chemical structures of these AMP analogues together with the structure of UMPC16.

HPLC analysis of AMPC16. Cells of Sac. cerevisiae IFO 0203 were grown in YPD medium overnight at $30^{\circ} \mathrm{C}$, harvested and washed with $50 \mathrm{mM}$ succinate buffer $(\mathrm{pH} \mathrm{6.5)}$. Washed cells were then suspended at the cell density of $10^{7} \mathrm{ml}^{-1}$ in the same buffer containing AMPC16 at $12 \cdot 5 \mu \mathrm{g} \mathrm{ml}^{-1}$ and incubated with shaking at $30^{\circ} \mathrm{C}$. At various times, portions of the cell suspension were withdrawn and subjected to centrifugal filtration in a membrane-equipped tube (ULTRAFREE-MC, Millipore). Each filtrate was then assayed for its content of AMPC16 by HPLC on an ODS reverse phase column $(6 \times 150 \mathrm{~mm})$ at the wavelength of $260 \mathrm{~nm}$. Isocratic elution was done at room temperature with $5 \mathrm{mM}\left(\mathrm{NH}_{4}\right) \mathrm{H}_{2} \mathrm{PO}_{4} /$ methanol $(20: 80, \mathrm{v} / \mathrm{v})$ and a flow rate of $1.0 \mathrm{ml} \mathrm{min}^{-1}$.

Assay of glucose-induced proton extrusion. Plasma membrane $\mathrm{H}^{+}$-ATPase activity was assayed in vivo by measuring the extracellular acidification due to glucose-induced proton extrusion by the intact cells, as described by Brandão et al. (1994). Cells were grown overnight in YPG medium at $30^{\circ} \mathrm{C}$, collected by centrifugation and washed several times with distilled water. Washed cells were then suspended in distilled water at the cell density of $10^{8} \mathrm{ml}^{-1}$ and the $\mathrm{pH}$ of the cell suspension was adjusted to $7 \cdot 0$ with dilute sodium hydroxide. After preincubating the cell suspension at $30^{\circ} \mathrm{C}$ for $10 \mathrm{~min}$, glucose was added at the final concentration of $100 \mathrm{mM}$ together with each of the other chemicals at the indicated concentrations. The $\mathrm{pH}$ of the cell suspension was measured using a Horiba $\mathrm{pH}$ meter model D-23 at $30^{\circ} \mathrm{C}$.

Preparation of plasma membrane fraction. Cells were grown in YPG medium at $30^{\circ} \mathrm{C}$ to mid-exponential phase, washed and suspended in $100 \mathrm{mM} \mathrm{N}$-[tris(hydroxymethyl)methyl]glycine buffer containing $5 \mathrm{mM}$ EDTA and $2 \mathrm{mM}$ DTT at the cell density of $10^{8} \mathrm{ml}^{-1}$. The cell suspension was incubated at $30^{\circ} \mathrm{C}$ for $10 \mathrm{~min}$ with supplementation with $100 \mathrm{mM}$ glucose to fully activate the plasma membrane $\mathrm{H}^{+}$-ATPase (Brandão et al., 1994). Cells were then collected, washed and resuspended in the above buffer at the cell density of 

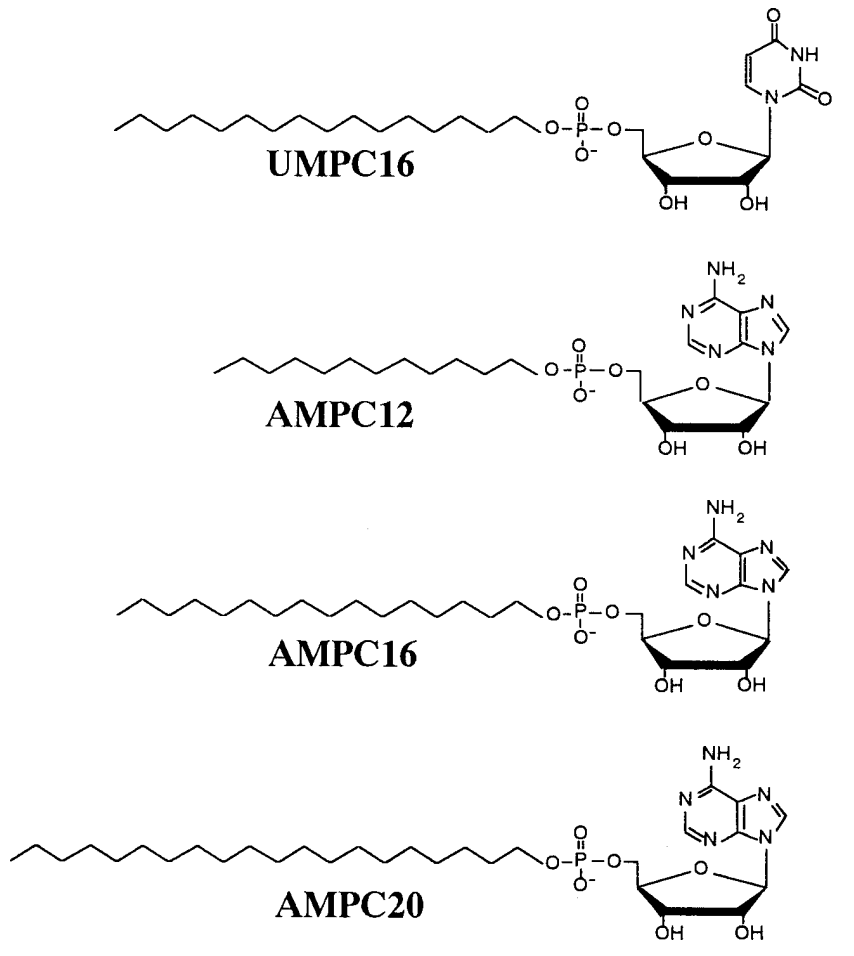

Fig. 1. Structures of UMPC16, AMPC12, AMPC16 and AMPC20.

$1 \cdot 5-2 \cdot 0 \times 10^{8} \mathrm{ml}^{-1}$, and then immediately frozen in liquid nitrogen and stored until use. The plasma membrane fraction was purified by ultracentrifugation according to the procedure described by Becher dos Passos et al. (1992). To measure the plasma membrane $\mathrm{H}^{+}$-ATPase activity in the cells with or without AMPC16 treatment, the plasma membrane fractions were prepared from the cells that had been incubated in distilled water containing both $100 \mathrm{mM}$ glucose and $10 \mathrm{mM}$ $\mathrm{MgSO}_{4}$ (adjusted to $\mathrm{pH} 7 \cdot 0$ ) at $30^{\circ} \mathrm{C}$ for 10 or $30 \mathrm{~min}$ as well as from cells that had been further supplemented with $25 \mu \mathrm{g}$ AMPC16 $\mathrm{ml}^{-1}$.

Assay of plasma membrane $\mathrm{H}^{+}$-ATPase. The enzyme activity was assayed on the basis of ATP hydrolysis by the plasma membrane preparation according to the method of Rosa \& Sá-Correia (1991) with a slight modification as follows. The standard reaction mixture contained $10 \mu \mathrm{mol}$ ATP, $10 \mu \mathrm{mol}$ $\mathrm{MgSO}_{4}, 50 \mu \mathrm{mol} \mathrm{KCl}$ and plasma membrane preparation equivalent to $0.3-0.4 \mathrm{mg}$ protein in $1.0 \mathrm{ml} 50 \mathrm{mM}$ Tris/Mes buffer ( $\mathrm{pH} 6 \cdot 0$ ). $\mathrm{KNO}_{3}, \mathrm{NaN}_{3}$ or ammonium molybdate was added at $200 \mu \mathrm{M}$ to inhibit vacuole-type ATPase, mitochondrial ATPase and acid phosphatase, respectively. After incubating the mixture at $30^{\circ} \mathrm{C}$ for $10 \mathrm{~min}$, inorganic phosphate liberated in the reaction was measured with a colorimetric phosphate assay kit (Wako Pure Chemicals). One unit of ATPase activity was defined as the amount of enzyme that liberated $1.0 \mathrm{nmol}$ inorganic phosphate $\mathrm{min}^{-1}(\mathrm{mg} \text { protein })^{-1}$. Protein was measured according to the method of Bradford (1976) using BSA as a standard.

Measurement of intracellular DAG level. Cells were grown in YPG medium at $30^{\circ} \mathrm{C}$ to mid-exponential phase, washed and suspended in distilled water containing both $100 \mathrm{mM}$ glucose and $10 \mathrm{mM} \mathrm{MgSO}_{4}$ (adjusted to $\mathrm{pH} 7 \cdot 0$ ) at the cell density of $10^{7}$ cells ml $\mathrm{m}^{-1}$ and incubated at $30^{\circ} \mathrm{C}$ with or without further supplementation with AMPC16 at $25 \mu \mathrm{g} \mathrm{ml}{ }^{-1}$. At various times, $30 \mathrm{ml}$ portions were withdrawn and the cells were collected by centrifugation. Lipids were extracted from the cell pellets by following our previously described method (Machida et al., 1999) for measurement of the DAG content using a radioenzymic assay (Preiss et al., 1986).

Chemicals. The following chemicals were purchased from Sigma: AMP, UMP, cerulenin, diethylstilboestrol (DES), amphotericin B, staurosporine and 1-oleoyl-2-acetyl-snglycerol (a membrane-permeable DAG analogue). The other chemicals were of analytical reagent grade.

\section{RESULTS AND DISCUSSION}

\section{Antimicrobial activities of nucleotide analogues}

In contrast to our previous finding on the growth inhibitory effect of AMPC16 on Sac. cerevisiae cells in the sexual agglutination assay (Machida et al., 1997), the nucleotide analogue did not inhibit the growth of yeast cells in YPD medium. The antimicrobial activity assays of AMPC16 were thus repeated in each medium with or without supplementation with $10 \mathrm{mM} \mathrm{MgSO}_{4}$ since the YHG medium used in the yeast mating process contained the magnesium salt at around $8 \mathrm{mM}$. No antimicrobial activity was observed with any UMP or AMP analogue, including AMPC16, against the bacterial and fungal strains tested at $100 \mu \mathrm{g} \mathrm{ml}^{-1}$, even in the presence of $\mathrm{Mg}^{2+}$. In contrast, all yeast strains tested except Rhodotorula rubra IFO 0001 were sensitive to AMPC16 with MIC values of $3 \cdot 13-25 \cdot 0 \mu \mathrm{g} \mathrm{ml}^{-1}$ when the cells were grown in YPD medium supplemented with $\mathrm{MgSO}_{4}$, as summarized in Table 1. Schizosaccharomyces pombe showed a different pattern of sensitivity to AMPC16, with growth inhibition in the absence as well as in the presence of $\mathrm{Mg}^{2+}$, although the presence of this divalent cation slightly increased the cytotoxic effect of AMPC16, as reflected by the lower MIC value. The growth inhibitory effects of AMP analogues on yeast cells critically depended on the length of the alkyl side chain since AMPC12 and AMPC20 were inactive even at $100 \mu \mathrm{g} \mathrm{ml}^{-1}$ in the medium with $\mathrm{Mg}^{2+}$. The turbidometric measurement of cell growth also revealed a potent growth inhibitory effect of AMPC16 on Sac. cerevisiae cells with a MIC value of $6 \cdot 25 \mu \mathrm{g} \mathrm{ml}^{-1}$ (Fig. 2). Under these conditions, the number of c.f.u. was gradually decreased with increasing time of incubation, reflecting the strong fungicidal activity of AMPC16. The $\mathrm{Mg}^{2+}$-dependent cytotoxic effect of AMPC16 on Sac. cerevisiae cells could be confirmed by a concomitant increase in the number of methylene blue stained cells (data not shown).

\section{Role of $\mathrm{Mg}^{2+}$ in the growth inhibitory effect of AMPC16}

In shaken cultures in YPD medium containing AMPC16 at $6.25 \mu \mathrm{g} \mathrm{ml} \mathrm{g}^{-1}$, the yeast cell growth was completely inhibited when either $\mathrm{MgSO}_{4}$ or $\mathrm{MgCl}_{2}$ was added at a concentration of at least $8 \mathrm{mM}$ but each magnesium salt was only partially effective at $5 \mathrm{mM}$. AMPC16 could not inhibit the growth of yeast cells in the absence of magnesium salts and the presence of $\mathrm{CaCl}_{2}$ or $\mathrm{BaCl}_{2}$ at 

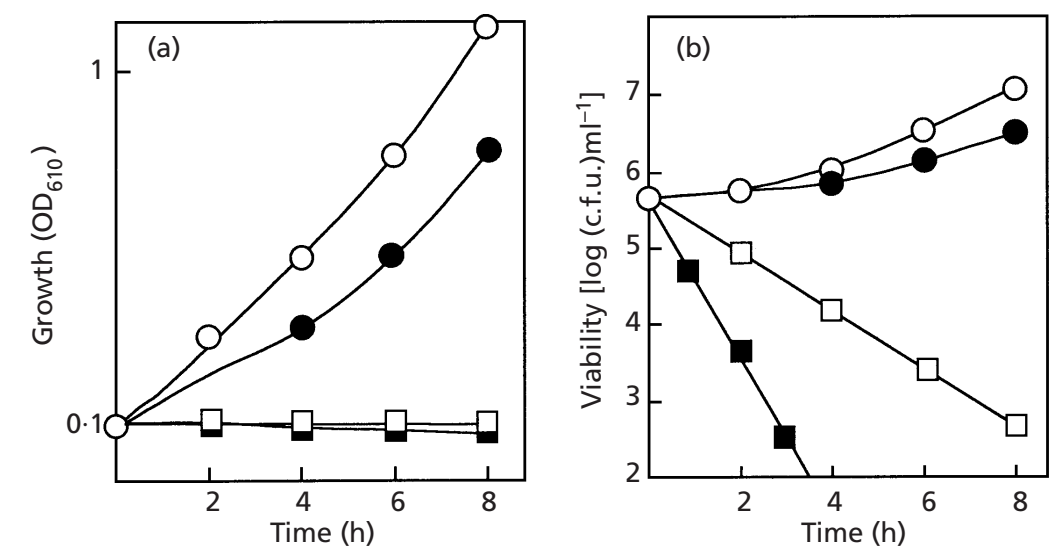

Fig. 2. Growth inhibitory effects of AMPC16 on Sac. cerevisiae. Cells were grown in YPD medium containing AMPC16 at $0(O), 3 \cdot 125$ (๑), 6.25 ( $\square$ ) or $12.5 \mu \mathrm{g} \mathrm{ml}^{-1}$ (品. Each medium was further supplemented with $10 \mathrm{mM} \mathrm{MgSO}_{4}$. Cell growth was measured by the turbidometric assay (a) and the viability assay, in which viable cell number was expressed as the number of c.f.u. (b).

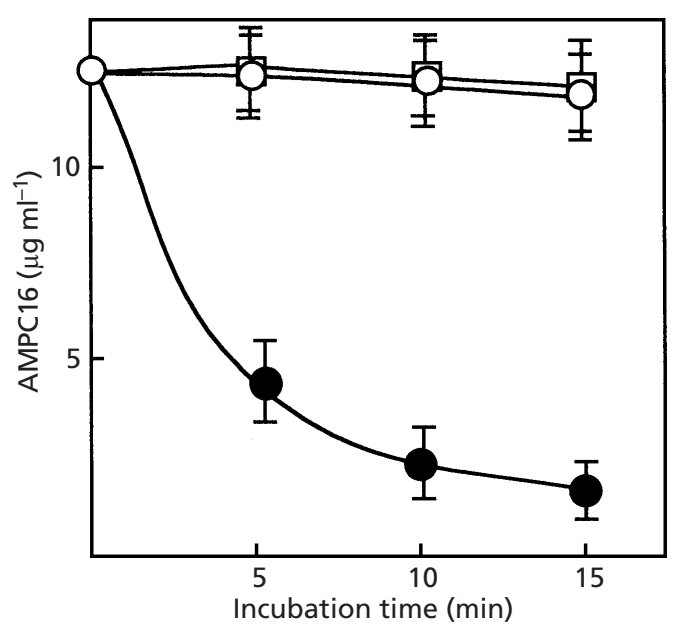

Fig. 3. Time course of the change of AMPC16 level in the suspension of Sac. cerevisiae cells. Cells were incubated in $50 \mathrm{mM}$ succinate buffer (pH 6.5) containing AMPC16 $\left(12.5 \mu \mathrm{g} \mathrm{ml}^{-1}\right.$ ) with no addition $(\square), 10 \mathrm{mM} \mathrm{CaCl}_{2}(\bigcirc)$ or $10 \mathrm{mM}$ $\mathrm{MgCl}_{2}(\mathbf{O})$. Values are means \pm SD of triplicate assays.

various concentrations up to $100 \mathrm{mM}$ and $25 \mathrm{mM}$, respectively. The effect of $\mathrm{MnCl}_{2}$ was examined at lower concentrations because of its own cytotoxic effect, and this salt was found to be ineffective when added at up to $5.0 \mathrm{mM}$. Thus, the fungicidal activity of AMPC16 was highly dependent on the presence of $\mathrm{Mg}^{2+} \cdot \mathrm{Mg}^{2+}$ is normally present in both the plasma membrane and cytoplasm of yeast cells and participates in a number of enzymic reactions using ATP as a substrate or product. Addition of exogenous $\mathrm{Mg}^{2+}$ may increase its concentrations in the above fractions so that it can accelerate the interaction between AMPC16 and the corresponding target molecule. The cytotoxic effect of AMPC16 was re-examined by the methylene blue method using the yeast cells which had been preincubated with YPD medium containing $10 \mathrm{mM} \mathrm{MgSO}{ }_{4}$ at $30{ }^{\circ} \mathrm{C}$ for $30 \mathrm{~min}$ and washed with freshly prepared YPD medium lacking $\mathrm{Mg}^{2+}$. Non-viable cells did not appear during a subsequent $2 \mathrm{~h}$ incubation of the $\mathrm{Mg}^{2+}$-pretreated cells in medium containing only AMPC16 at $25 \mu \mathrm{g} \mathrm{m} \mathrm{l}^{-1}$, but did appear when $\mathrm{Mg}^{2+}$ was re-added. This indicates that the $\mathrm{Mg}^{2+}$-pretreated cells lost their susceptibility to AMPC16 easily upon simple washing, suggesting that $\mathrm{Mg}^{2+}$ promotes the cytotoxic action of AMPC16 via a reversible interaction with a cell surface component. HPLC analysis detected AMPC16 at almost the original level throughout the incubation with or without $10 \mathrm{mM}$ $\mathrm{Ca}^{2+}$, as shown in Fig. 3. In contrast, the addition of $\mathrm{Mg}^{2+}$ accelerated the disappearance of AMPC16 from the incubation mixture, possibly by enabling its incorporation into or uptake across the plasma membrane. It remains to be determined how $\mathrm{Mg}^{2+}$ could stimulate the cellular uptake of AMPC16 in Sac. cerevisiae cells, whilst the uptake occurred in $S c h$. pombe cells without the aid of exogenous $\mathrm{Mg}^{2+}$ (see Table 1).

\section{Inhibitory effects of AMPC16 on glucose-induced extracellular acidification}

Inhibition of long-chain acyl-CoA synthetase seems likely to influence the cell growth more seriously than inhibition of adenylate cyclase and ribonuclease, since long-chain acyl-CoA is essential for the biosynthetic reactions of phospholipids, major constituents of the plasma membrane (Tomoda et al., 1991). In Sac. cerevisiae cells, however, fatty acid synthetase can substitute for long-chain acyl-CoA synthetase since the enzyme can produce long-chain fatty acids in the form of the corresponding CoA derivative using acetyl-CoA and malonyl-CoA as starting materials (Johnson et al., 1994). Cerulenin is a typical inhibitor of both fatty acid synthetase and 3-hydroxy-3-methylglutaryl-CoA synthetase, a key enzyme for ergosterol biosynthesis (Omura, 1976). This antibiotic restricted the growth of Sac. cerevisiae cells after several hours of incubation during which exhaustion of fatty acids or lipid components pre-existing in the YPD medium may have occurred, as deduced from the protective effects of exogenous long-chain fatty acids against cerulenininduced growth inhibition (Knoll et al., 1995). The growth-inhibition pattern of cerulenin was characterized by a lack of appearance of non-viable cells, in contrast to the pattern of AMPC16 (see Fig. 2). Instead of focusing on these cytoplasmic enzymes, we focused 


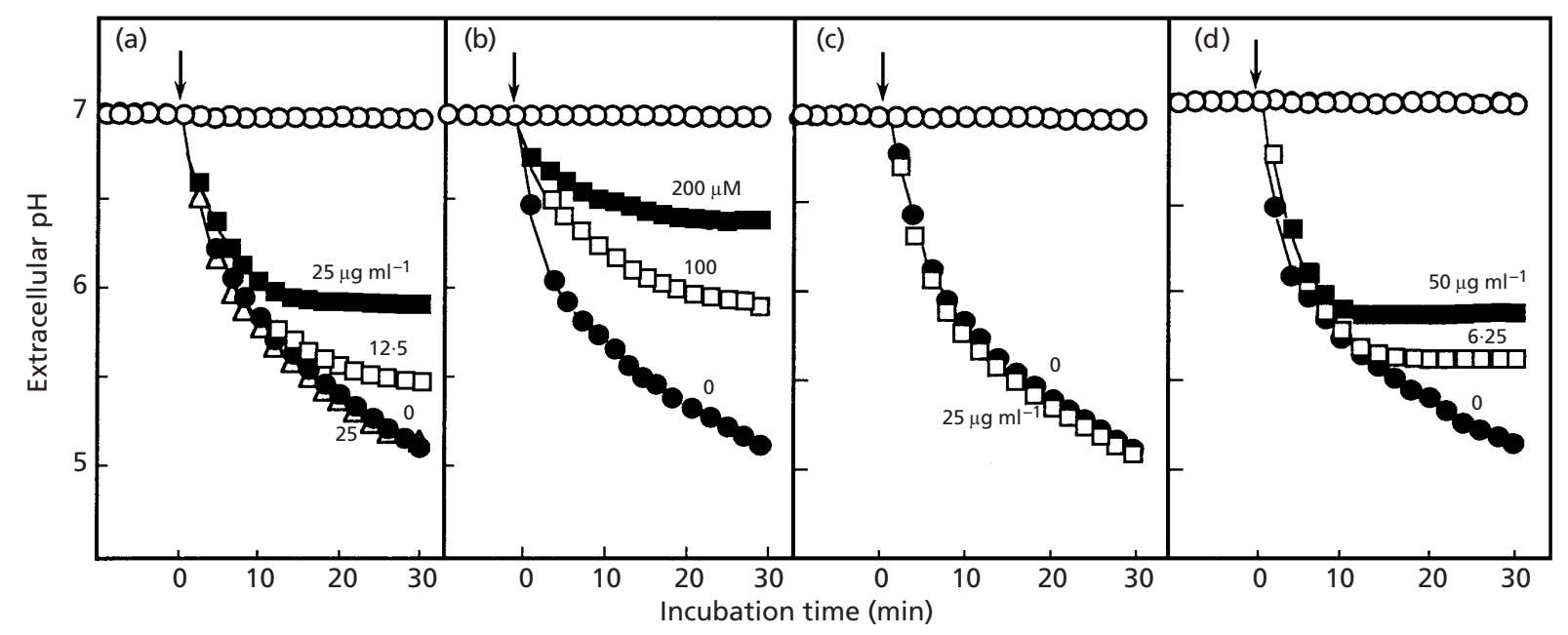

Fig. 4. Effects of AMPC16 (a), DES (b), cerulenin (c) and amphotericin B (d) on glucose-induced extracellular acidification by cells of Sac. cerevisiae. Cells were incubated in distilled water (adjusted to $\mathrm{pH} 7 \cdot 0$ ) as a control (O) and incubated in water containing $100 \mathrm{mM}$ glucose alone (O) or both $100 \mathrm{mM}$ glucose and each of the above chemicals at the indicated concentrations $(\square, \boldsymbol{q})$. In (a), the cell suspensions $(O, \mathbf{Q}, \square, \boldsymbol{\square})$, except $(\triangle)$, were further supplemented with $10 \mathrm{mM}$ $\mathrm{MgSO}_{4}$. Arrows indicate the time of addition of glucose and each chemical. The pattern of extracellular acidification in each column represents the most representative one from triplicate assays.

on the proton extrusion catalysed by the ATP-dependent reaction associated with the plasma membrane phospholipid bilayer, which has been evaluated as a target of cytotoxic agent (Monk et al., 1995). This enzymic reaction is essential for cell viability because of its function as a proton pump that regulates cytoplasmic $\mathrm{pH}$ and provides the driving force for nutrient uptake (Serrano et al., 1986; Serrano, 1989).

Lapathitis \& Kotyk (1998) reported that the glucoseinduced extracellular acidification depends on both proton extrusion resulting from the action of the plasma membrane $\mathrm{H}^{+}$-ATPase and the cellular excretion of glucose-derived carbon dioxide and organic acids. In that study, the extent of contribution of the latter process was examined by using strain Y55 and its isogenic mutant, pmal-105, with a genetic lack of the enzyme. This process was estimated to contribute only $6.9 \%$ of the overall glucose-induced acidification on the basis of the rate of increase in the extracellular proton concentration predicted from the $\mathrm{pH}$ value. As shown in Fig. 4(a), the glucose-induced extracellular acidification initially proceeded without apparent inhibition in AMPC16-treated cells, but was later drastically inhibited in a dose-dependent manner. As can be deduced from the $\mathrm{pH}$ values (predicted proton concentrations) at the $30 \mathrm{~min}$ incubation, the extracellular acidification was inhibited by $25 \mu \mathrm{g} \mathrm{ml} \mathrm{m}^{-1}$ AMPC16 much more than expected from an inhibition of the glucoseinduced process with no relation to plasma membrane $\mathrm{H}^{+}$-ATPase. The extracellular $\mathrm{pH}$ change was not provoked by incubating the cells only with AMPC16 at $25 \mu \mathrm{g} \mathrm{ml}^{-1}$ and $10 \mathrm{mM} \mathrm{MgSO}_{4}$, but was initiated with a similar inhibition pattern after addition of glucose. AMPC16 could cause complete cell death at $25 \mu \mathrm{g} \mathrm{ml}^{-1}$ in such an experiment using an increased cell density $\left(10^{8}\right.$ cells $\left.\mathrm{ml}^{-1}\right)$, suggesting a correlation between its inhibitory effect on the action of plasma membrane $\mathrm{H}^{+}$ATPase and the $\mathrm{Mg}^{2+}$-dependent cytotoxicity. The glucose-induced extracellular acidification was also markedly inhibited by $200 \mu \mathrm{M}$ DES (Fig. 4b), which can directly interfere with the action of plasma membrane $\mathrm{H}^{+}$-ATPase (Wach et al., 1990). The extent of extracellular acidification, possibly due to excretion of carbon dioxide and organic acids, was likewise estimated to be less than $10 \%$ after a 30 min incubation. AMPC16 was not likely to exhibit a protonophoric activity such as promoting passive influx of extracellular protons since the extracellular $\mathrm{pH}$ remained unchanged in the cell suspension with no glucose when the initial $\mathrm{pH}$ was adjusted to $5 \cdot 0$. These findings indicate that the inhibition of glucose-induced extracellular acidification is due to the inhibitory effect of AMPC16 on the proton pumping function of the plasma membrane $\mathrm{H}^{+}$-ATPase. As already suggested, based on its mode of action, cerulenin did not cause any inhibition of the glucoseinduced process during $30 \mathrm{~min}$ incubation (Fig. 4c). Amphotericin B exerts an antifungal effect by causing damage of the plasma membrane phospholipid bilayers as a result of its complex formation with ergosterol (Herve et al., 1989). Its inhibitory effect on the cellular proton extrusion thus could be a secondary effect resulting from the plasma membrane disruption (Fig. $4 d)$.

\section{Interference with activation of plasma membrane $\mathrm{H}^{+}$-ATPase by AMPC16}

In the present study, the ATPase activity in the plasma membrane fraction was assayed in order to examine whether AMPC16 can directly inhibit ATP hydrolysis. 
Table 2. Effects of AMPC16 on ATPase activity of the plasma membrane fraction

\begin{tabular}{|lccc|}
\hline Chemical & Concn & $\begin{array}{c}\text { ATPase } \\
\text { activity* }\end{array}$ & $\begin{array}{c}\text { Relative } \\
\text { activity (\%) }\end{array}$ \\
\hline None & $25 \mu \mathrm{g} \mathrm{ml}^{-1}$ & $448 \pm 60$ & 100 \\
AMPC16 & $250 \mu \mathrm{g} \mathrm{ml}^{-1}$ & $423 \pm 50$ & 107 \\
& $20 \mu \mathrm{M}$ & $273 \pm 37$ & 65 \\
DES & $200 \mu \mathrm{M}$ & $62 \pm 20$ & 15 \\
Amphotericin B & $25 \mu \mathrm{g} \mathrm{ml}^{-1}$ & $117 \pm 31$ & 28 \\
\hline
\end{tabular}

*Values are shown as nmol $\min ^{-1}\left(\mathrm{mg}\right.$ protein $\left.{ }^{-1}\right)$ and are means \pm SD of triplicate assays.

As summarized in Table 2, the enzyme activity was significantly inhibited by either DES or amphotericin B, but not by AMPC16. Plasma membrane $\mathrm{H}^{+}$-ATPase purified from bakers' yeast exhibited a loss of catalytic ability to hydrolyse ATP, but it was found to recover the original activity after reconstitution with a phospholipid component such as phosphatidylserine (Koland \& Hammes, 1986). By analogy, the amphotericin Bmediated inhibition of the enzyme activity may be caused by an inhibition of the functional interaction between the enzyme protein and phospholipids in the isolated plasma membrane fraction.

The plasma membrane fractions were also prepared from cells which had been incubated under the same conditions as in Fig. 4(a) to examine the effect of AMPC16 on the level of active $\mathrm{H}^{+}$-ATPase. In triplicate assays, the enzyme activity was detected at a level of $424 \pm 75$ units (mg protein) ${ }^{-1}$ after 10 min incubation with $100 \mathrm{mM}$ glucose alone and it was then significantly reduced to the level of $250 \pm 53$ units $(\mathrm{mg} \text { protein })^{-1}$ during another $20 \mathrm{~min}$ incubation. The enzyme activity was detected at the significantly reduced level of $42 \pm 21$ units (mg protein) ${ }^{-1}$ in AMPC16-treated cells at $10 \mathrm{~min}$ incubation and remained within a similar range during another $20 \mathrm{~min}$ incubation. The mechanism of the effect of AMPC16 on the plasma membrane $\mathrm{H}^{+}$-ATPase should have involved inhibition of the enzyme activity in vivo or interference with its activation.

\section{Relationship between AMPC16-induced events and DAG}

The plasma membrane $\mathrm{H}^{+}$-ATPase from Sac. cerevisiae is phosphorylated on multiple serine and threonine residues during its movement into the cell surface from the endoplasmic reticulum (Chang \& Slayman, 1991). Phosphorylation of the enzyme is associated with an increased ATPase activity during growth on glucose. Upon glucose starvation, dephosphorylation occurs, together with a decrease in enzymic activity, and both are rapidly reversed upon re-addition of glucose. Sitespecific phosphorylation is likely to regulate the ATPase activity in response to nutritional signals. It is known that the cellular cAMP level shows a rapid increase under the above conditions in which $\mathrm{H}^{+}$-ATPasedependent proton extrusion occurs at the fully stimulated rate (Morishita et al., 1995), suggesting a cAMPdependent mechanism for the site-specific phosphorylation of the enzyme. However, yeast strains that are specifically deficient in the glucose-induced cAMP increase still show normal activation of plasma membrane $\mathrm{H}^{+}$-ATPase (Becher dos Passos et al., 1992). Moreover, yeast mutants with widely divergent levels of cAMPdependent protein kinase activity display very similar levels of activation of the enzyme.

On the other hand, the addition of a membranepermeable DAG analogue or other activators of protein kinase C (PKC) (Ogita et al., 1990) to intact cells activates the $\mathrm{H}^{+}$-ATPase and at the same time causes a stimulation of proton extrusion from the cells (Brandão et al., 1994). Both effects are reversed by the addition of staurosporine, a PKC inhibitor, which can cause a more potent inhibition of the enzyme activation when added together with calmidazolium, an inhibitor of $\mathrm{Ca}^{2+}$ / calmodulin-dependent protein kinase (Brandão et al., 1994). These results have suggested a model that explains glucose-induced activation of the enzyme via a phosphatidylinositol-type signalling pathway triggering phosphorylation of the enzyme by both PKC and $\mathrm{Ca}^{2+} /$ calmodulin-dependent protein kinase. As shown in Fig. 5(a), the exogenous addition of DAG analogue could largely cancel the inhibitory effect of AMPC16 on cellular proton extrusion although its protective effect was not enhanced at a higher concentration (data not shown). The DAG analogue did not protect cells against the inhibition of glucose-induced proton extrusion by staurosporine (Fig. 5b). These results agree with the above model in which AMPC16 acts as an antagonist of phosphatidylinositol-type signalling that mediates glucose-induced activation of plasma membrane $\mathrm{H}^{+}$ATPase.

Our findings suggested that AMPC16 inhibited the cellular generation of $s n-1,2-\mathrm{DAG}$ in response to a nutritional signal from glucose rather than directly interfering with the action of PKC. A radioenzymic assay has been used for the measurement of the intracellular level of DAG and has revealed a decrease of DAG along with apoptosis of various mammalian cells (Melnykovych et al., 1992; Haug et al., 1994). As shown in Fig. 6, the intracellular DAG level showed an immediate response to the addition of glucose, being increased to a maximum value at $10 \mathrm{~min}$ incubation, with a subsequent decrease to the original level. In contrast, in AMPC16-treated cells, the DAG level did not increase in response to glucose; instead DAG was decreased to a minimum level during the initial $10 \mathrm{~min}$ incubation. A mutant lacking PLC1-encoded phospholipase $\mathrm{C}$ gave clearer evidence showing the participation of a phosphatidylinositol-type signal in glucose-induced activation of plasma membrane $\mathrm{H}^{+}$-ATPase (Coccetti et al., 1998). In cells of the mutant strain, the glucose signal did not provoke the increase in the DAG level and failed to activate the plasma membrane $\mathrm{H}^{+}$-ATPase.

In previous studies, we found a potent growth-inhibitory 


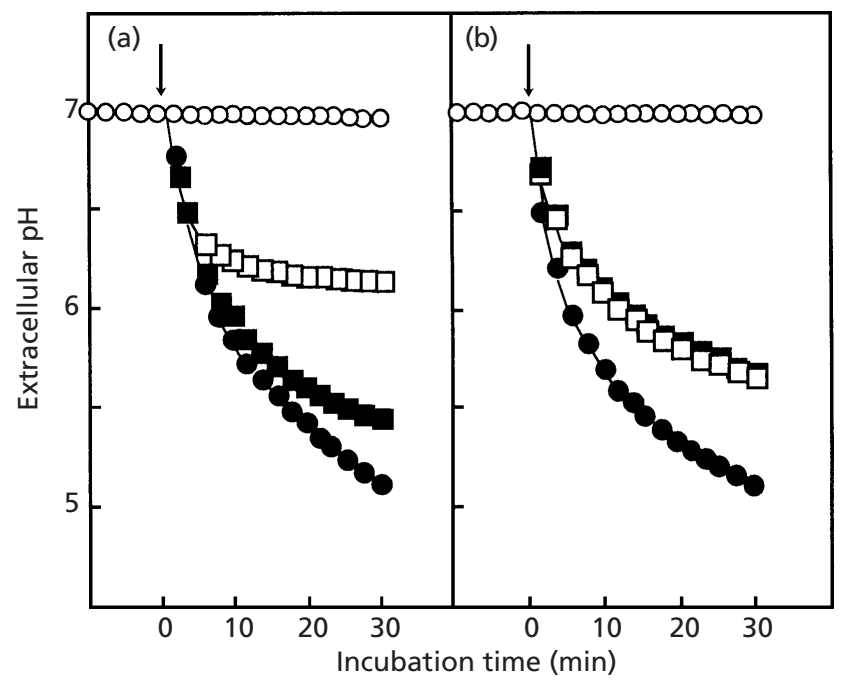

Fig. 5. Protective effects of a membrane-permeable DAG analogue on the inhibition of glucose-induced proton extrusion by AMPC16 (a) and staurosporine (b). Cells were incubated in distilled water (adjusted to $\mathrm{pH}$ 7.0) as a control (O). In (a), cells were incubated in distilled water (adjusted to $\mathrm{pH} 7.0$ ) containing $100 \mathrm{mM}$ glucose and $10 \mathrm{mM} \mathrm{MgSO}_{4}$ with $(\square, \boldsymbol{\square})$ or without (O) further addition of AMPC16 at $25 \mu \mathrm{g} \mathrm{ml}^{-1}$. In (b), cells were incubated in distilled water (adjusted to $\mathrm{pH} 7.0$ ) containing $100 \mathrm{mM}$ glucose with $(\square, \boldsymbol{\square})$ or without $(\bullet)$ further addition of staurosporine at $50 \mu \mathrm{M}$. In both experiments, the DAG analogue was added at $30 \mu \mathrm{M}$ ( $\square$ ). Arrows indicate the time of addition of glucose and each chemical. Each extracellular acidification curve is the most representative one from triplicate assays.

effect of the isoprenoid farnesol on Sac. cerevisiae cells, which was characterized by a transition of the budded to unbudded phase together with a decrease of intracellular DAG (Machida et al., 1999). Unlike the farnesol-induced apoptosis of mammalian cells (Haug et al., 1994; Voziyan et al., 1995), farnesol-treated yeast cells were still viable but were prevented from progressing through the cell cycle for a very long period (Machida et al., 1998, 1999). This means that the simple loss of DAG could not be the cause of the death in Sac. cerevisiae cells. As mentioned, complete inhibition of glucoseinduced activation of plasma membrane $\mathrm{H}^{+}$-ATPase was achieved by the combined addition of staurosporine and calmidazolium (Brandão et al., 1994). On the other hand, AMPC16 alone maximally inhibited glucoseinduced proton extrusion so that its inhibition could not be completely reversed by exogenous addition of DAG (see Fig. 5). AMPC16 should exert an additional inhibitory effect on a DAG-independent mechanism for activation of plasma membrane $\mathrm{H}^{+}$-ATPase, on the assumption that this inhibitory effect can account for the cell death. Alternatively, the fungicidal effect of AMPC16 may arise from the combined inhibition of $\mathrm{H}^{+}-$ ATPase and some other enzyme such as long-chain acylCoA synthetase or adenylate cyclase, which can be a target of this nucleotide analogue in other organisms (Shiraishi et al., 1994; Hynie \& Smrt, 1978). These possibilities are currently under investigation.

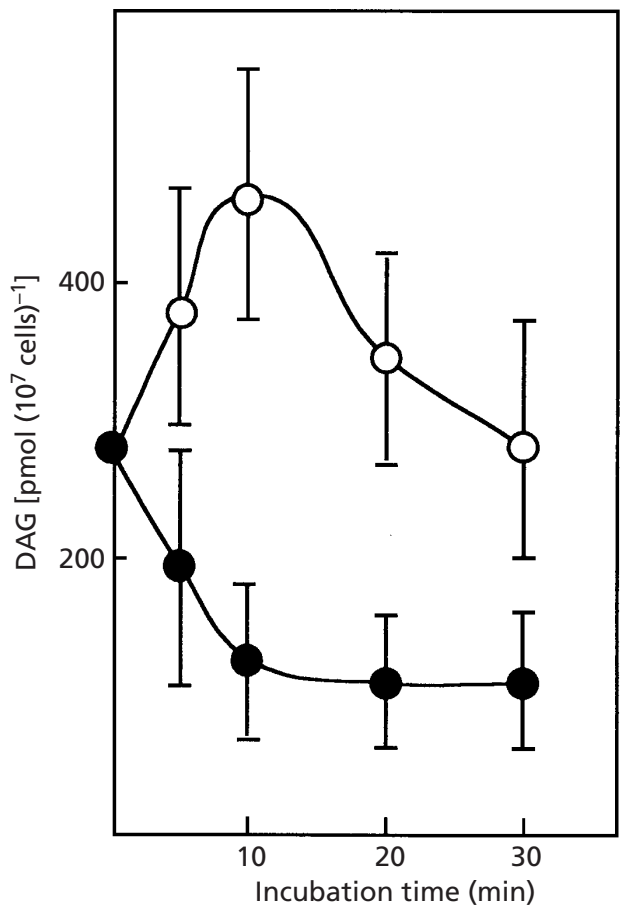

Fig. 6. Time course of the change of the intracellular DAG level during incubation with or without AMPC16. Cells were incubated in distilled water (adjusted to $\mathrm{pH} 7 \cdot 0$ ) containing $100 \mathrm{mM}$ glucose and $10 \mathrm{mM} \mathrm{MgSO}_{4}(\bigcirc)$ or in this solution further supplemented with AMPC16 at $25 \mu \mathrm{g} \mathrm{ml}^{-1}$ (). Lipid fractions were prepared and the DAG in each fraction was measured as described in Methods. Values are means \pm SD of triplicate assays.

\section{REFERENCES}

Akeda, Y., Shibata, K., Ping, X., Tanaka, T. \& Taniguchi, M. (1995). AKD-2A, B, C and D, new antibiotics from Streptomyces sp. OCU-42815: taxonomy, fermentation, isolation, structure elucidation and biological activity. $J$ Antibiot 48, 363-368.

Baltch, A. L., Smith, R. P., Ritz, W. J. \& Bopp, L. H. (1998). Comparison of inhibitory and bactericidal activities and postantibiotic effects of LY333328 and ampicillin used singly and in combination against vancomycin-resistant Enterococcus faecium. Antimicrob Agents Chemother 42, 2564-2568.

Becher dos Passos, J., Vanhalewyn, M., Brandão, R. L., Castro, I. M., Nicoli, J. R. \& Thevelein, J. M. (1992). Glucose-induced activation of plasma membrane $\mathrm{H}^{+}$-ATPase in mutants of the yeast Saccharomyces cerevisiae affected in cAMP metabolism, cAMP-dependent protein phosphorylation and the initiation of glycolysis. Biochim Biophys Acta 1136, 57-67.

Bradford, M. M. (1976). A rapid and sensitive method for the quantification of microgram quantities of protein utilizing the principle of protein-dye binding. Anal Biochem 72, 248-254.

Brandão, R. L., de Magalhaes-Rocha, N. M., Alijo, R., Ramos, J. \& Thevelein, J. M. (1994). Possible involvement of a phosphatidylinositol-type signaling pathway in glucose-induced activation of plasma membrane $\mathrm{H}^{+}$-ATPase and cellular proton extrusion in the yeast Saccharomyces cerevisiae. Biochim Biophys Acta 1223, 117-124.

Chang, A. \& Slayman, C. W. (1991). Maturation of the yeast 
plasma membrane $\left[\mathrm{H}^{+}\right]$ATPase involves phosphorylation during intracellular transport. J Cell Biol 115, 289-295.

Coccetti, P., Tisi, R., Martegani, E., Sousa Teixeira, L., Brandão, R. L., Castro, I. M. \& Thevelein, J. M. (1998). The PLC1 encoded phospholipase C in the yeast Saccharomyces cerevisiae is essential for glucose-induced phosphatidylinositol turnover and activation of plasma membrane $\mathrm{H}^{+}$-ATPase. Biochim Biophys Acta 1405, 147-154.

Haug, J. S., Goldner, C. M., Yazlovitskaya, E. M., Voziyan, P. A. \& Melnykovych, G. (1994). Directed cell killing (apoptosis) in human lymphoblastoid cells incubated in the presence of farnesol: effect of phosphatidylcholine. Biochim Biophys Acta 1223, 133-140.

Herve, M., Debouzy, J. C., Borowski, E., Cybulska, B. \& GaryBobo, C. M. (1989). The role of the carboxyl and amino groups of polyene macrolides in their interactions with sterols and their selective toxicity: a phosphorus-31 NMR study. Biochim Biophys Acta 980, 261-272.

Hynie, S. \& Smrt, J. (1978). Effects of adenosine 5'-phosphate esters with lipid hydroxy compounds (adenosine nucleolipids) on the activity of enzymes of cyclic AMP system. FEBS Lett 94, 339-341.

Johnson, D. R., Knoll, L. J., Rowley, N. \& Gordon, J. I. (1994). Genetic analysis of the role of Saccharomyces cerevisiae acyl-CoA synthetase genes in regulating protein $\mathrm{N}$-myristoylation. $\mathrm{J} \mathrm{Biol}$ Chem 269, 18037-18046.

Knoll, L. J., Johnson, D. R. \& Gordon, J. I. (1995). Complementation of Saccharomyces cerevisiae strains containing fatty acid activation gene (FAA) deletions with a mammalian acyl-CoA synthetase. J Biol Chem 270, 10861-10867.

Kohner, P. C., Patel, R., Uhl, J. R., Garin, K. M., Hopkins, M. K., Wegener, L. T. \& Cockerill, F. R., III (1997). Comparison of agar dilution, broth microdilution, E-test, disk diffusion, and automated Vitek methods for testing susceptibilities of Enterococcus spp. to vancomycin. J Clin Microbiol 35, 3258-3263.

Koland, J. G. \& Hammes, G. G. (1986). Steady state kinetic studies of purified yeast plasma membrane proton-translocating ATPase. J Biol Chem 261, 5936-5942.

Lapathitis, G. \& Kotyk, A. (1998). Different sources of acidity in glucose-elicited extracellular acidification in the yeast Saccharomyces cerevisiae. Biochem Mol Biol Int 46, 973-978.

Machida, K., Tanaka, T., Shibata, K. \& Taniguchi, M. (1997). Inhibitory effects of nucleotide $5^{\prime}$-alkylphosphate on sexual agglutination in Saccharomyces cerevisiae. FEMS Microbiol Lett $147,17-22$.

Machida, K., Tanaka, T., Fujita, K. \& Tanaguchi, M. (1998). Farnesol-induced generation of reactive oxygen species via indirect inhibition of the mitochondrial electron transport chain in the yeast Saccharomyces cerevisiae. J Bacteriol 180, 4460-4465.

Machida, K., Tanaka, T., Yano, Y., Otani, S. \& Taniguchi, M. (1999). Farnesol-induced growth inhibition in Saccharomyces cerevisiae by a cell cycle mechanism. Microbiology 145, 293-299.

Manfredi, J. P., Klein, C., Herrero, J. J., Byrd, D. A., Trueheart, J., Wiesler, W. T., Fowlkes, D. M. \& Broach, J. R. (1996). Yeast alpha mating factor structure-activity relationship derived from genetically selected peptide agonists and antagonists of Ste2p. Mol Cell Biol 16, 4700-4709.

Melnykovych, G., Haug, J. S. \& Goldner, C. M. (1992). Growth inhibition of leukemia cell line CEM-C1 by farnesol: effects of phosphatidylcholine and diacylglycerol. Biochem Biophys Res Commun 186, 543-548.

Monk, B. C., Mason, A. B., Abramochkin, G., Haber, J. E., SetoYoung, D. \& Perlin, D. S. (1995). The yeast plasma membrane proton pumping ATPase is a viable antifungal target. I. Effects of the cysteine-modifying reagent omeprazole. Biochim Biophys Acta 1239, 81-90.

Morishita, T., Mitsuzawa, H., Nakafuku, M., Nakamura, S., Hattori, S. \& Anraku, Y. (1995). Requirement of Saccharomyces cerevisiae Ras for completion of mitosis. Science 270, 1213-1215.

Ogita, K., Miyamoto, S., Koide, H. \& 7 other authors (1990). Protein kinase C in Saccharomyces cerevisiae: comparison with the mammalian enzyme. Proc Natl Acad Sci USA 87, 5011-5015.

Omura, S. (1976). The antibiotic cerulenin, a novel tool for biochemistry as an inhibitor of fatty acid synthesis. Bacteriol Rev 40, 681-697.

Preiss, J., Loowis, C. R., Bishop, R. W., Stein, R., Niedel, J. E. \& Bell, R. M. (1986). Quantitative measurement of $s n$-1, 2-diacylglycerols present in platelets, hepatocytes, and ras- and sis-transformed normal rat kidney cells. J Biol Chem 616, 8597-8600.

Rodriguez, R. J. \& Parks, L. W. (1981). Physiological response of Saccharomyces cerevisiae to 15 -azasterol-mediated growth inhibition. Antimicrob Agents Chemother 20, 184-189.

Rosa, M. F. \& Sá-Correia, I. (1991). In vivo activation by ethanol of plasma membrane ATPase of Saccharomyces cerevisiae. Appl Environ Microbiol 57, 830-835.

Serrano, R. (1989). Structure and function of plasma membrane ATPase. Annu Rev Plant Physiol 40, 61-94.

Serrano, R., Kielland-Brandt, M. C. \& Fink, G. R. (1986). Yeast plasma membrane ATPase is essential for growth and has homology with $\left(\mathrm{Na}^{+}, \mathrm{K}^{+}\right), \mathrm{K}^{+}$- and $\mathrm{Ca}^{2+}$-ATPases. Nature 319, 689-693.

Shiraishi, T., Tezuka, K. \& Uda, Y. (1994). Selective inhibition of lignoceroyl-CoA synthase by adenosine $5^{\prime}$-alkylphosphates. FEBS Lett 352, 353-355.

Tomoda, H., Igarashi, K., Cyong, J. C. \& Omura, S. (1991). Evidence for an essential role of long chain acyl-CoA synthetase in animal cell proliferation: inhibition of long chain acyl-CoA synthetase by triacsins caused inhibition of Raji cell proliferation. J Biol Chem 266, 4214-4219.

Ueki, M., Abe, K., Hanafi, M., Shibata, K., Tanaka, T. \& Taniguchi, M. (1996). UK-2A, B, C and D, novel antifungal antibiotics from Streptomyces sp. 517-02. I. Fermentation, isolation, and biological properties. J Antibiot 49, 639-643.

Voziyan, P. A., Haug, J. S. \& Melnykovych, G. (1995). Mechanism of farnesol cytotoxicity: further evidence for the role of PKCdependent signal transduction in farnesol-induced apoptotic cell death. Biochem Biophys Res Commun 212, 479-486.

Wach, A., Ahlers, J. \& Graeber, P. (1990). The proton-ATPase of the plasma membrane from yeast: kinetics of ATP hydrolysis in native membranes, isolated and reconstituted enzymes. Eur J Biochem 189, 675-682.

Yasuda, T. \& Inoue, Y. (1983). Steady-state kinetic studies of binding and catalysis by ribonuclease T2: a microenvironment survey of the active site by using a series of adenosine- $3^{\prime}-$ and $-5^{\prime}$ alkylphosphates. J Biochem 94, 1475-1481.

Received 11 October 1999; accepted 25 October 1999. 